\title{
Ethnomedicinal Plants and their Traditional Use for Treatment of Diabetes in Kokrajhar District of Assam, India
}

\author{
P. Sarmah ${ }^{1 *}$, M. Neog ${ }^{2}$, M. K. Bhuyan ${ }^{1}$ and P. Basumatary ${ }^{1}$ \\ ${ }^{1}$ Krishi Vigyan Kendra, Kokrajhar, Assam Agricultural University, Gossaigaon, Assam, India \\ ${ }^{2}$ Directorate of Extension Education, Assam Agricultural University, Jorhat, Assam, India \\ *Corresponding author
}

\section{A B S T R A C T}

\begin{tabular}{|l|}
\hline K e y w or d s \\
Ethnomedicinal, \\
Herbs, Traditional, \\
Ailment, Diabetes
\end{tabular}

\section{Introduction}

Medicinal plants have important contributions in the healthcare system of local communities across the world for almost all types of ailments. Out of the total 422,000 flowering plants reported from the world, more than 50,000 are used for medicinal purposes (Hamilton, 2004). The healing power of traditional herbal medicines has been realized and documented since Rigveda and Atharvaveda, most of which involve the use of plant extracts In last few decades, traditional knowledge on primary healthcare has been widely acknowledged across the world. It is estimated that $60 \%$ of the world population and $80 \%$ of the population of developing countries rely on traditional medicine, mostly plant drugs, for their primary health care needs (Shrestha and Dhillion, 2003).

The highest popularity of medicinal plant in rural areas is due to high cost of allopathic drugs and side effects. Traditionally used medicinal plants have been a source of relief in controlling different types of diseases throughout the globe.

Among many other different aliments, Diabetes Mellitus is considered to be a metabolic disorder and $2.8 \%$ of the world's 
population suffers from this disease and it is expected to increase to more than $5.4 \%$ by 2025. Various research and reviews have demonstrated the benefits of medicinal plants containing hypoglycemic properties in diabetes management. The most common herbal active ingredients used in treating diabetes are flavonoids, tannins, phenolic, and alkaloids.

Further, the mechanisms of actions for hypoglycemic plants includes increasing of insulin secretion, increasing of glucoses absorption by muscle and fat tissues, prevention of glucose absorption from the intestine, and prevention of glucose production from liver cells. (Kooti et al., 2016).

These factors are mostly responsible for the reduction or elimination of diabetes complications through enthomedicinal plants abundantly available in nature.

Therefore, there is an urgent need to document the medicinal and aromatic plants associated traditional knowledge, because this knowledge orally passes on from one generation to the next; thus, have vulnerability to wiped out (Kala, 2005).

Most of the medicinal plants used by local people and tribes of the state of Assam are indigenous and are not known to the vast world of phytochemical science and research. The active ingredients and potent phytochemicals with promising pharmacological properties present in those plants are yet to be explored and some are in the pipeline (Sarmah and Das, 2018).

Traditional use of plants and plant-parts has been a deep rooted practical knowledge in the culture and livelihood of the people living in the remote district like Kokrajhar in the state of Assam. They have been using different medicinal plants in their daily health care practices. Plant parts used more frequently are in form of bark, leaf, tuber, fruits, roots etc. The present study was aimed at investigating the traditional utilization of medicinal plants located in Kokrajhar district of Assam in order to identify and explore plant species that are used locally for treatment of human ailments particularly diabetes and also to document traditional formulation from these medicinal plants

\section{Materials and Methods}

The present study was carried out in four (4) health blocks or 11 development block of Kokrajhar district of Assam. A total of 100 respondents were selected on the basis of information provided by the local administrator and elder people of the study areas. Prior to survey, a semi structured interview schedule was designed and pre tested with five respondents to find out its suitability for the present study and later on it was modified according to response of respondents.

The revised schedule was used for collecting data from individual respondent about medicinal plants of the study area. Indigenous technological knowledge (ITK) on medicinal properties of edible species was also collected in the same manner from the respondents. Their scientific names, vernacular names and family were identified consulting literatures. Traditional uses of the plant species were supported with relevant literatures.

\section{Results and Discussion}

Data collected from 100 respondents reveals that 23 plant species were in use for medicinal purposes, specifically for diabetes management. Traditional uses of the plant species were discussed with reference to the relevant literatures (Fig. 1 and Table 1). 
Table.1 Ethnomedicinal plants and their traditional use for treating diabetes in Kokrajhar district of Assam

\begin{tabular}{|c|c|c|c|}
\hline $\begin{array}{l}\text { Sl. } \\
\text { No. }\end{array}$ & Plant species & Traditional use & Reported phytochemical/pharmacological activities \\
\hline $\mathbf{1}$ & $\begin{array}{l}\text { Annona squamosa } \mathrm{L} \\
\text { Family: Annonaceae } \\
\text { Common name: } \\
\text { Custard apple } \\
\text { Vernacular names: } \\
\text { Assamese: Attaphol, } \\
\text { Atlas, Ata kothal, } \\
\text { Sita phol } \\
\text { Bodo: Aithaphol }\end{array}$ & $\begin{array}{l}\text { Raw bark or/and } \\
\text { leaves of custard } \\
\text { apple are grinded } \\
\text { and the extracts are } \\
\text { obtained r by } \\
\text { squishing. The } \\
\text { extract is then } \\
\text { filtered and used } 2 \\
\text { to } 3 \text { tea spoonfull of } \\
\text { extract } \\
\text { morning. }\end{array}$ & $\begin{array}{l}\text { The plant is reported to contain glycosides, flavonoids, } \\
\text { phenolic compounds, proteins, tannins, bio active } \\
\text { compounds like Anonaine, aporphine, norcorydine, } \\
\text { glaucine, geraniol, etc. It acts as anti-diabetic, anti- } \\
\text { microbial having pesticide effect. Flavonoids are } \\
\text { reported to possess antidiabetic activity. } \\
\text { Phytochemical analysis of leaves of A. squamosa Linn. } \\
\text { revealed the presence of flavonoids. which can be used } \\
\text { as potential antidiabetic drug } \\
\text { (Tomar and Sisidia, 2014). }\end{array}$ \\
\hline 2 & $\begin{array}{l}\text { Azadirachta indica } \\
\text { A.Juss } \\
\text { Family: Meliaceae } \\
\text { Common Name: } \\
\text { Neem } \\
\text { Vernacular names: } \\
\text { Assamese: Neem } \\
\text { Bodo:Neem }\end{array}$ & $\begin{array}{l}\text { Raw leaf extracts of } \\
\text { Neem is mixed with } \\
\text { little water and } 2-3 \\
\text { tea spoonful is taken } \\
\text { daily in empty } \\
\text { stomach }\end{array}$ & $\begin{array}{l}\text { Neem extract which have Nimbinin, nimbandiol as } \\
\text { active constituents, alcoholic extract of the leaves is } \\
\text { found to possess a significant blood sugar lowering } \\
\text { effect, which are very useful against diabetes. (Uddin } \\
\text { et al., 2018) } \\
\text { Bio active compounds are Azadirachtin, meliacin, } \\
\text { salanin, nimbin and valassin etc. Various biological } \\
\text { and pharmacological activity of the plant includes- } \\
\text { anthelminthic, antibacterial, antiulcer, anti-fertility, } \\
\text { anti-diabetic, anti-inflammatory, antiviral, anti- } \\
\text { malarial, diuretic, insecticidal, anti-spermatogenic, } \\
\text { antitumor, hypo-glycaemic, etc (Giri et al., 2019) }\end{array}$ \\
\hline 3 & $\begin{array}{l}\text { Cateranthus } \\
\text { roseus(L.) G.Don } \\
\text { Family: Apocynaceae } \\
\text { Common Name: } \\
\text { Bright eye } \\
\text { Vernacular names: } \\
\text { Assamese: Nayantara } \\
\text { phul } \\
\text { Bodo: Daodwi bibar }\end{array}$ & $\begin{array}{l}\text { fresh leaf } \\
\text { eye may be } \\
\text { in empty stc }\end{array}$ & $\begin{array}{l}\text { The plant has immense medicinal importance for its } \\
\text { alkaloids. All parts of the plant including leaf, root, } \\
\text { shoot and stem contains more than } 200 \text { alkaloids, } \\
\text { which are used for therapeutic purposes against several } \\
\text { diseases. The most important alkaloids vinblastine and } \\
\text { vincristine are derived from leaves and they exhibits } \\
\text { anti-cancer and anti-diabetic property and alkaloid } \\
\text { rubacine derived from roots is used as hypotensive and } \\
\text { anti-arrhythmic agent. (Gupta et al.,2017). } \\
\text { The leaf and flower are extensively used to treat } \\
\text { diabetes and it promotes insulin production in human } \\
\text { body. (Gomaa et al., 2019) }\end{array}$ \\
\hline 4 & $\begin{array}{l}\text { Centella asiatica }(\mathrm{L} . \\
\text { Urban) } \\
\text { Family: } \\
\text { Mackinlayaceae } \\
\text { Common Name: }\end{array}$ & $\begin{array}{l}\text { Centella asiatica is a } \\
\text { traditionally } \\
\text { important plant with } \\
\text { wide range of } \\
\text { therapeutic potential } \\
\text { Two to three (2-3) } \\
\text { tea spoonful of fresh }\end{array}$ & $\begin{array}{l}\text { Madecassic acid, asiatic acid, } \alpha \text {-terpinene, } \alpha \text {-copaene, } \\
\beta \text {-caryophyllene are some of the important bioactive } \\
\text { compounds responsible for its antioxidant, } \\
\text { antimicrobial, antiulcer, antifilarial, antiviral and anti } \\
\text { diabetic activies etc. The Methanolic and ethanolic } \\
\text { extract of C.asiatica revealed considerable protection } \\
\text { and reduce the blood sugar level to normal. (Zahara } e t\end{array}$ \\
\hline
\end{tabular}




\begin{tabular}{|c|c|c|c|}
\hline & $\begin{array}{l}\text { Indian Pennywort } \\
\text { Vernacular names: } \\
\text { Assamese: Manimuni } \\
\text { Bodo: } \\
\text { Manimoni }\end{array}$ & $\begin{array}{l}\text { leaf extracts of } \\
\text { Indian Pennywort } \\
\text { are taken in empty } \\
\text { stomach nearly for } \\
21 \text { days in the early } \\
\text { diabetic conditions. }\end{array}$ & al., 2015). \\
\hline 5 & $\begin{array}{l}\text { Citrullus colocynthis } \\
\text { (L.) Schrad } \\
\text { Family: } \\
\text { Cucurbitaceae. } \\
\text { Common Name: } \\
\text { Bitter apple fruit } \\
\text { Vernacular names: } \\
\text { Assamese:Kuwa } \\
\text { baturi } \\
\text { Bodo: khuwa bhaturi }\end{array}$ & $\begin{array}{l}\text { The bark of the red } \\
\text { ripens fruit of bitter } \\
\text { apple is dried and } \\
\text { powdered. Five to } \\
\text { ten(5-10) gm } \\
\text { powder is taken with } \\
\text { water in empty } \\
\text { stomach. }\end{array}$ & $\begin{array}{l}\text { All the part of plant (root, stem, leaf, fruit and Seed) } \\
\text { are utilized in traditional system of medicine and } \\
\text { different parts of the plant are believed to have anti- } \\
\text { diabetic, anti-hyper-lipidemic, laxative, anti- } \\
\text { inflammatory, analgesic, vermifuge, hair-growth- } \\
\text { promoting, antibacterial, antifungal and antioxidant } \\
\text { properties.(Dhakad, et al., 2017). } \\
\text { The bio active compounds found are Quercetin, iso- } \\
\text { vitexin, colocynthoside A \& B, cucurbitacin E 2-O- } \\
\text { beta-D-glcoside etc. Citrullus colocynthis plant was } \\
\text { traditionally used for the treatment of diabetes. } \\
\text { Application of } 125 \text { mg C. colocynthis once per day for } \\
2 \text { months can lead to considerable decrease in the } \\
\text { mean levels of HbA1c and FBS among the patients } \\
\text { with type II diabetes without any side effects. } \\
\text { (Asadollahi et al., 2015). } \\
\text { Moreover, Meena et al., (2014) documented that pulp } \\
\text { of ripe fruit trembled in naked feet for } 15 \text { days was } \\
\text { used to treat diabetes by tribes of Rajasthan. }\end{array}$ \\
\hline 6 & $\begin{array}{l}\text { Kalanchoe pinnata } \\
\text { (Lam.) Pers. } \\
\text { Family: Crassulaceae. } \\
\text { Common Name: } \\
\text { Air plant/ life plant/ } \\
\text { miracle leaf } \\
\text { Vernacular names: } \\
\text { Assamese:Pataygoja } \\
\text { Bodo: Patgaza }\end{array}$ & $\begin{array}{l}1 \mathrm{~g} \text { of raw leaves of } \\
\text { air plant is grinded } \\
\text { with } 100 \mathrm{ml} \text { of } \\
\text { water. } 2-3 \text { tea } \\
\text { spoonful of the leaf } \\
\text { extract are taken } \\
\text { early in the morning. }\end{array}$ & $\begin{array}{l}\text { The plant has biological property like antimicrobial, } \\
\text { anti-inflammatory, anti-allergic, anti-anaphylactic, } \\
\text { anti-leishmanial, immunosuppressive, insecticidal etc. } \\
\text { Sunayana et al., (2016) in his study reported that } \\
\text { extracts of K. pinnata proved to be the potential } \\
\text { antidiabetic drug. }\end{array}$ \\
\hline 7 & $\begin{array}{l}\text { Momordica charantia } \\
\text { L. } \\
\text { Family: } \\
\text { Cucurbitaceae } \\
\text { Common Name: } \\
\text { Bitter gourd. } \\
\text { Vernacular names: } \\
\text { Assamese: } \\
\text { Tita kerela }\end{array}$ & $\begin{array}{l}\text { Bitter gourd is a } \\
\text { tropical plant which } \\
\text { bears intensely bitter } \\
\text { fruits usually used in } \\
\text { cooking as well as } \\
\text { used as a natural } \\
\text { remedy to treat } \\
\text { various ailment 20- } \\
30 \text { ml of fresh } \\
\text { extracts of bitter } \\
\text { gourd are taken in } \\
\text { empty stomach }\end{array}$ & 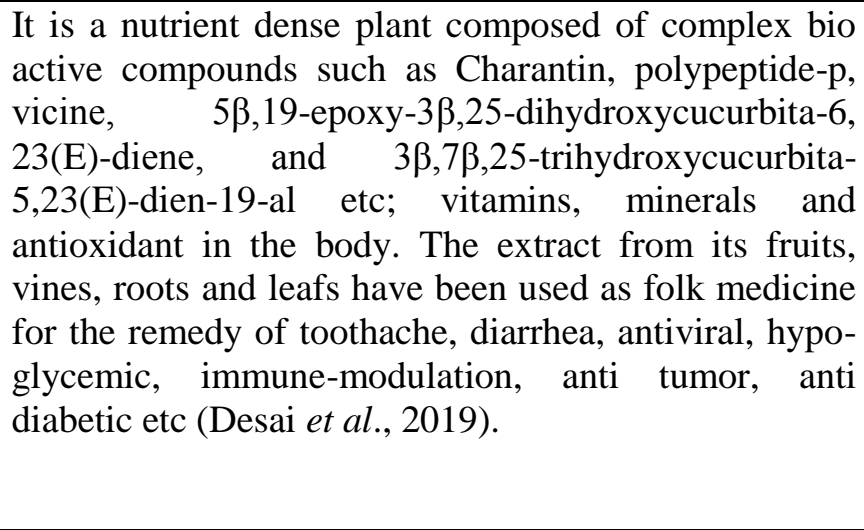 \\
\hline
\end{tabular}




\begin{tabular}{|c|c|c|c|}
\hline & $\begin{array}{l}\text { Bodo: } \\
\text { Tita kerela }\end{array}$ & & \\
\hline 8 & $\begin{array}{l}\text { Solanum } \\
\text { xanthocarpum Schrad } \\
\text { and Wendl. } \\
\text { Family: Solanaceae. } \\
\text { Common Name: } \\
\text { Yellow fruit night } \\
\text { shade. } \\
\text { Vernacular names: } \\
\text { Assamese: } \\
\text { Tita bekhuri } \\
\text { Bodo: } \\
\text { Ambu fanthao }\end{array}$ & $\begin{array}{l}\text { Solanum } \\
\text { xanthocarpum is a } \\
\text { prickly herb is } \\
\text { immensely mportant } \\
\text { (one of the members } \\
\text { of Dasamula of the } \\
\text { Ayurveda) in } \\
\text { traditional system of } \\
\text { medicine The juice } \\
\text { extract of the fresh } \\
\text { fruits (1-3 no.) is } \\
\text { taken as remedy to } \\
\text { the high blood } \\
\text { glucose in the body }\end{array}$ & $\begin{array}{l}\text { Solanum xanthocarpum is an important medicinal herb } \\
\text { in ayurvedic medicine. Fruit juice is useful in sour } \\
\text { throat, rheuthematism and decoctation of fruit of the } \\
\text { plant is used by tribes of Orissa to treat } \\
\text { Diabetes.(Parmar et al., 2010). } \\
\text { The Bio active compounds found are Campesterol, } \\
\text { daucosterol and triterpenes like cycloartanol and } \\
\text { cycloartenol. The fruits are known for several } \\
\text { medicinal uses like anthelmintic, antipyretic, laxative, } \\
\text { anti-inflammatory, anti-asthmatic and aphrodisiac } \\
\text { activities, anti-hyperglycemic property. Leaf extract of } \\
\text { Solanum xanthocarpum is effecttvely lower the blood } \\
\text { glucose level and increase the production of insulin. } \\
\text { (Tekuri et al.,2019) }\end{array}$ \\
\hline 9 & $\begin{array}{l}\text { Stellaria media } \\
\text { (L.)Vill } \\
\text { Family: } \\
\text { Caryophyllaceae. } \\
\text { Common Name: } \\
\text { Chick weed. } \\
\text { Vernacular names: } \\
\text { Assamese: Morolya } \\
\text { Bodo: Morolya }\end{array}$ & $\begin{array}{l}\text { Stellaria media }(L .) \\
\text { Vill plant is widely } \\
\text { dispersed all over } \\
\text { the world.Intake of } \\
\text { two to three tea } \\
\text { spoonfull of aqueous } \\
\text { extracts of the whole } \\
\text { plant of chick weed } \\
\text { in empty stomach is } \\
\text { beneficial to help } \\
\text { reduce the glucose } \\
\text { concentration in } \\
\text { blood }\end{array}$ & $\begin{array}{l}\text { Chick weed has been used as therapeutic substance } \\
\text { since time immemorial and revealed important } \\
\text { secondary metabolites such as flavonoid, } \\
\text { oligosaccharide stellariose, anthraquinone derivatives, } \\
\text { fatty acid, steroid saponins and phenolic compounds. } \\
\text { Different parts of the plant have been used to treat } \\
\text { various gastrointestinal disorders, asthma, diarrhoea, } \\
\text { measles, jaundice, renal, digestive, reproductive and } \\
\text { respiratory tracts inflammations and also lessen } \\
\text { swelling and used as plasters for broken bones. } \\
\text { Flavonoids undergo metabolic processes to combat } \\
\text { diabetic complications and enhance insulin secretion, } \\
\text { proliferation of pancreatic } \beta \text {-cells and it also reduces } \\
\text { oxidative stress, insulin resistance, apoptosis and } \\
\text { inflammation in muscles (Oladeji et al., 2020). } \\
\text { Bhuyan (2015) also reported that the whole plant } \\
\text { extract of chick weed was used to treat Diabetes } \\
\text { traditionally by the tribes of Bongaigoan district. }\end{array}$ \\
\hline 10 & $\begin{array}{l}\text { Murraya koeningii L. } \\
\text { Spreng } \\
\text { Family: Rutaceae. } \\
\text { Common Name: } \\
\text { Curry leaves. } \\
\text { Vernacular names: } \\
\text { Assamese: } \\
\text { Narasingha } \\
\text { Bodo: } \\
\text { Nwrshing. }\end{array}$ & $\begin{array}{l}\text { Curry leaf is a } \\
\text { potential medicinal } \\
\text { plant highly valued } \\
\text { for its characteristic } \\
\text { aroma and bioactive } \\
\text { compound. } \\
\text { Two to three(2-3) } \\
\text { tea spoonful of Leaf } \\
\text { extract of Curry leaf } \\
\text { is taken early in the } \\
\text { morning }\end{array}$ & $\begin{array}{l}\text { Murraya koenigii has diverse role in traditional } \\
\text { medicine and is known for its stomachic properties. } \\
\text { The plant is rich source of carbazole alkaloids. In } \\
\text { addition, it also contains Phyto compounds like } \\
\text { koenimbine, koenine, mahanimbine, murrayazolidine, } \\
\text { murrayazoline, murrayacine, girinimbine, mukoeic } \\
\text { acid etc. These bioactive compounds possess } \\
\text { antioxidant, antimicrobial, anthelmintic, anticancer, } \\
\text { analgesic, antidiabetic, anti-inflammatory, } \\
\text { antidiarrheal, hepato protective and antitumor } \\
\text { properties. (Gahlawat et al., 2014). Bhuyan, (2015) } \\
\text { documented that the leaf extract of curry is beneficial } \\
\text { to treat Diabetes mellitus to a great extent. }\end{array}$ \\
\hline 11 & Phlogocanthus & Phlogacanthus & This plant has been known to possess antibacterial, \\
\hline
\end{tabular}




\begin{tabular}{|c|c|c|c|}
\hline & $\begin{array}{l}\text { thyrsiflorus (Nees) } \\
\text { Family: Acanthaceae. } \\
\text { Common Name: } \\
\text { Nongmangkha. } \\
\text { Vernacular names: } \\
\text { Assamese: } \\
\text { Ronga Titaphul/ranga } \\
\text { bahak/banheka } \\
\text { Bodo: } \\
\text { Basikar bibar }\end{array}$ & $\begin{array}{l}\text { thyrsiflorus is a } \\
\text { gregarious evergreen } \\
\text { shrub which is used } \\
\text { in several traditional } \\
\text { medicines to cure } \\
\text { various diseases. } \\
\text { Two to three tea } \\
\text { spoonful of fresh } \\
\text { leaf extract of } \\
\text { Nongmangkha is } \\
\text { taken early in the } \\
\text { morning }\end{array}$ & $\begin{array}{l}\text { antifungal, anti diabetic, anti-inflammatory, anti } \\
\text { cancerous, hypolipidaemic and hepatoprotective } \\
\text { activity. Phytochemical constituents isolated from the } \\
\text { plant are flavonoids, tannins, phytosterols, phenol, } \\
\text { glycosides, fatty acids, galacto-glycero lipid and } \\
\text { volatile oil etc. Gogoi et al., (2013) also reported the } \\
\text { anti diabetic properties of leaf extract of } \\
\text { Nongmangkha. }\end{array}$ \\
\hline 12 & $\begin{array}{l}\begin{array}{l}\text { Hodgsonia heteroclite } \\
\text { (Roxb.) }\end{array} \\
\text { Family: Cucurbitacea. } \\
\text { Common Name: } \\
\text { Chinese Lard Plant. } \\
\text { Vernacular names: } \\
\text { Assamese: Thebau } \\
\text { latal } \\
\text { Khaum. } \\
\text { Bodo: } \\
\text { jwgwnar Hagrani }\end{array}$ & $\begin{array}{l}\text { Two to three (2- } \\
\text { 3)tea spoonful of } \\
\text { fresh or dry extracts } \\
\text { of the fruit juice is } \\
\text { taken in empty } \\
\text { stomach }\end{array}$ & $\begin{array}{l}\text { Hodgsonia heteroclita(Roxb.) is one of the high oil } \\
\text { yielding traditional food as well as medicines used by } \\
\text { tribal communities inhibiting North east hills of India. } \\
\text { (Bhatt et al.,2014) } \\
\text { Phytochemicals like phenolics, flavonoids, alkaloids, } \\
\text { saponins and steroids are also present in Chinese lard } \\
\text { plant. The plant possess good antioxidant activity and } \\
\text { less quantity of toxic metals, which therefore can be } \\
\text { used as a source of natural free radical scavenger. } \\
\text { Further, fruit pulp of } H \text {. heteroclita is traditionally } \\
\text { used as antidiabetic medicine. (Swargiary and Brahma, } \\
\text { 2017; Basumatary et al., 2015). }\end{array}$ \\
\hline 13 & $\begin{array}{l}\text { Spinacia oleracea } \\
\text { Family: } \\
\text { Amaranthaceae. } \\
\text { Common Name: } \\
\text { Spinach. } \\
\text { Vernacular names: } \\
\text { Assamese: Paleng } \\
\text { saak. } \\
\text { Bodo: Paleng shaak. }\end{array}$ & $\begin{array}{l}\text { About } 200 \mathrm{~g} \text { of } S \text {. } \\
\text { oleracea are mixed } \\
\text { with an equal } \\
\text { amount of fresh } \\
\text { carrot and grounded } \\
\text { to obtain juice which } \\
\text { is taken every day in } \\
\text { empty stomach }\end{array}$ & $\begin{array}{l}\text { Spinach is packed with vitamins such as vitamin C, } \\
\text { vitamin A and vitamin E and minerals like } \\
\text { magnesium, manganese, iron, calcium and folic acid. } \\
\text { It is a good source of the bioflavonoid quercetin with } \\
\text { many other flavonoids. Moreover, it is also used to } \\
\text { prevent the bone loss associated with osteoporosis and } \\
\text { for its anti-inflammatory properties in easing the pain } \\
\text { of arthritis. Spinach is good for the heart and } \\
\text { circulatory system and has energy-boosting properties. } \\
\text { Spinach is truly one of nature's most perfect foods } \\
\text { (Mehta and Balemkar, 2014). } \\
\text { Azad and Islam(2018) states that Spinach leaf extract } \\
\text { have very good anti diabetic properties and also } \\
\text { compound like Saponin, tannin and alkaloid are found } \\
\text { in Spinach leaf. }\end{array}$ \\
\hline 14 & $\begin{array}{l}\text { Erythrina variegate L } \\
\text { Family: Fabaceae. } \\
\text { Common Name: } \\
\text { Tiger's claw/ Indian }\end{array}$ & $\begin{array}{l}\text { The Erythrina } \\
\text { variegate L plant is } \\
\text { commonly known as } \\
\text { Tiger's Claw and } \\
\text { exhibit medicinal } \\
\text { properties. Fresh }\end{array}$ & $\begin{array}{l}\text { Devaki et al., (2016) found that the aqueous extract of } \\
\text { E. variegata exerted a hypoglycemic effect. In } \\
\text { addition, the extract positively functions on pancreas } \\
\text { and provide evidence for its traditional usage in the } \\
\text { control of diabetes. } \\
\text { Hemalakhmi and Devaki (2017) mentioned that the }\end{array}$ \\
\hline
\end{tabular}




\begin{tabular}{|c|c|c|c|}
\hline & $\begin{array}{l}\text { coral tree. } \\
\text { Vernacular names: } \\
\text { Assamese: Modar } \\
\text { Ghos } \\
\text { Bodo:Mandar }\end{array}$ & $\begin{array}{l}\text { roots are ground for } \\
\text { obtaining juice. } \\
\text { About } 25 \mathrm{ml} \text { of juice } \\
\text { are taken for } 1 \text { week } \\
\text { without water. }\end{array}$ & $\begin{array}{l}\text { antidiabetic activity of ethanolic extract of Erythrina } \\
\text { variegata L flowers have more number of secondary } \\
\text { metabolites (phenols, alkaloids, flavonoids etc.) } \\
\text { followed by bark extract and is effective to treat } \\
\text { diabetes patients.-Nagar and Chauhan (2015) reported } \\
\text { that the extract of Erythrina variegate L have potential } \\
\text { to decrease Blood glucose level as well as improving } \\
\text { hyper lipidermia and thus reduce complications } \\
\text { associate with Diabetes mellitus. }\end{array}$ \\
\hline 15 & $\begin{array}{l}\text { Phyllanthus emblica } \\
\text { Family: } \\
\text { Phyllanthaceae. } \\
\text { Common Name: } \\
\text { Amla. } \\
\text { Vernacular names: } \\
\text { Assamese: Amlokhi } \\
\text { Bodo: Amlai }\end{array}$ & $\begin{array}{l}\text { Phyllanthus emblica } \\
\text { L. is commonly } \\
\text { known as Indian } \\
\text { gooseberry and used } \\
\text { for both as edible } \\
\text { (tonic) plants and } \\
\text { therapeutic } \\
\text { potentials. About } 10 \\
\text { numbers of fruits are } \\
\text { ground-and juice are } \\
\text { mixed with honey } \\
\text { and taken every day }\end{array}$ & $\begin{array}{l}\text { P. emblica is highly nutritious and is reported as an } \\
\text { important dietary source of vitamin C, minerals and } \\
\text { amino acids. Moreover, all parts of the plant are used } \\
\text { for medicinal purposes, especially the fruit, which has } \\
\text { been used in Ayurveda as a potent Rasayana } \\
\text { (rejuvenator). In addition, } P \text {. emblica contains } \\
\text { phytochemicals including fixed oils, phosphatides, } \\
\text { essential oils, tannins, minerals, vitamins, amino acids, } \\
\text { fatty acids, glycosides, etc. Various pharmaceutical } \\
\text { potential of } P \text {. emblica has been reported previously } \\
\text { including antimicrobial, antioxidant, anti- } \\
\text { inflammatory, analgesic and antipyretic, adaptogenic, } \\
\text { hepatoprotective, antitumor and antiulcerogenic } \\
\text { activities either in combined formulation or } P \text {. emblica } \\
\text { alone. Further, the leaf extract of E. officinalis exerted } \\
\text { rapid protective effect against lipid per oxidation by } \\
\text { scavenging free radicals and reducing the risk of } \\
\text { diabetis complications. (Gaire and Subedi, 2015). }\end{array}$ \\
\hline 16 & $\begin{array}{l}\text { Rubus fruticosus L. } \\
\text { Family: Rosaceae. } \\
\text { Common Name: } \\
\text { Mulberry/ black } \\
\text { berry. } \\
\text { Vernacular names: } \\
\text { Assamese: } \\
\text { Nuni phol } \\
\text { Bodo: } \\
\text { Thaishreel } \\
\text { Gwswm bwigri. }\end{array}$ & $\begin{array}{l}\text { Rubus fruticosus L. } \\
\text { is a shrub famous } \\
\text { for its fruit called } \\
\text { blackberry fruit } \\
\text { which has } \\
\text { medicinal, cosmetic } \\
\text { and nutritive value. } \\
\text { Dried barks of the } \\
\text { plant is soaked into } \\
\text { water for } 12 \text { hours } \\
\text { and filtered. The } \\
\text { filtrate } \\
\text { (approximately } 30 \\
\text { ml) is taken every } \\
\text { day in empty } \\
\text { stomach for } 1 \\
\text { month. }\end{array}$ & $\begin{array}{l}\text { Rubus fruticosus } \mathrm{L} \text { is a concentrated source of valuable } \\
\text { nutrients, as well as bioactive constituents of } \\
\text { therapeutic interest highlighting its importance as a } \\
\text { functional food. Moreover, it also contains vitamins, } \\
\text { steroids and lipids in seed oil and minerals, flavonoids, } \\
\text { glycosides, terpenes, acids and tannins in aerial parts } \\
\text { that possess diverse pharmacological activities such as } \\
\text { antioxidant, anti-carcinogenic, anti-inflammatory, } \\
\text { antimicrobial anti-diabetic, anti-diarrheal, and } \\
\text { antiviral.(Haq et al.,2014). } \\
\text { Motevalian and Javadpour (2017) in his study found } \\
\text { that oral administration of aqueous extract of black } \\
\text { berry leaves can have the blood sugar lowering effect } \\
\text { and reduce serum lipid in liver. }\end{array}$ \\
\hline 17 & $\begin{array}{l}\text { Vigna mungo L } \\
\text { Family: Fabaceae. } \\
\text { Common Name: } \\
\text { Black gram }\end{array}$ & $\begin{array}{l}\text { Black gram is one } \\
\text { of the most } \\
\text { nutritious beans and } \\
\text { is commonly used } \\
\text { for its wide health } \\
\text { benefits and } \\
\text { consumed ay }\end{array}$ & $\begin{array}{l}\text { Blackgram helps in improve our digestion as it is } \\
\text { filled with fibers that help with the bulking up and } \\
\text { movement of stool therefore combat both } \\
\text { constipation as well as diarrhea. It is very good for } \\
\text { patients with diabetes as it regulates the glucose } \\
\text { levels in the blood. In addition it is good for skin and } \\
\text { can help fight dark spots, acne, and marks. It is also }\end{array}$ \\
\hline
\end{tabular}




\begin{tabular}{|c|c|c|c|}
\hline & $\begin{array}{l}\text { Vernacular names: } \\
\text { Assamese: Matimah } \\
\text { Bodo: Hani sobai }\end{array}$ & $\begin{array}{l}\text { cooking and also } \\
\text { used in Ayurvedic } \\
\text { medicine. About } 50 \\
\mathrm{~g} \text { of raw blackgram } \\
\text { seeds ground and } \\
\text { soaked in } 1 \text { cup of } \\
\text { milk overnight and } \\
\text { taken for } 20 \text { days. }\end{array}$ & $\begin{array}{l}\text { helpful with joint pain, is extremely good for the } \\
\text { heart, and is also a diuretic that helps keeps body } \\
\text { clean. Firdous and Marwah,2020; Girish et al.,2019; } \\
\text { Nitin et al., 2012) } \\
\text { Vigna Mungo L is nutritionally rich and consumed for } \\
\text { the purpose of lowering the blood glucose level of } \\
\text { Diabetic patient in rural areas. (Ayenewu, 2017) } \\
\text { The extract of V. mungo having low glycemic index } \\
\text { and high fibre content is helpful in the treatment of } \\
\text { obesity and type } 2 \text { diabetes ( Kaur et al., } 2015 \text {. }\end{array}$ \\
\hline 18 & $\begin{array}{l}\text { Curcuma longa } \mathrm{L} \\
\text { Family: } \\
\text { Zingiberaceae. } \\
\text { Common Name: } \\
\text { Turmeric. } \\
\text { Vernacular names: } \\
\text { Assamese:Halodhi. } \\
\text { Bodo: Haldw }\end{array}$ & $\begin{array}{l}\text { About } 8 \mathrm{~g} \text { of raw } \\
\text { turmeric were } \\
\text { grinded, mixed with } \\
\text { water and } 1 / 2 \text { tea } \\
\text { spoonfull of honey } \\
\text { and taken for one }(1) \\
\text { month after meal }\end{array}$ & $\begin{array}{l}\text { Curcumin present in turmeric is actively involved in } \\
\text { treatment of diabetes and diabetic disorders, which } \\
\text { included liver disorders, adipocyte dysfunction, } \\
\text { neuropathy, nephropathy, vascular diseases, } \\
\text { pancreatic } \beta \text { cell dysfunction, and other complications. } \\
\text { Curcumin favorably affect most of the leading aspects } \\
\text { of diabetes, including insulin resistance, } \\
\text { hyperglycemia, hyperlipidemia, and islet apoptosis and } \\
\text { necrosis. (Zhang et al., 2013). } \\
\text { In a study conducted bt Hodaei et al., 2019) found that } \\
\text { daily administration of } 1500 \text { mg curcumin has positive } \\
\text { effects in reducing fasting blood glucose and weight in } \\
\text { patients with type } 2 \text { diabetes. } \\
\text { Rivera et al., (2019) found that curcumin (or } \\
\text { curcuminoids) is a hypoglycemic agent or act as an } \\
\text { adjuvant to improve the metabolic profile and also to } \\
\text { ameliorate the associated complications of diabetes } \\
\text { mellitus, such as diabetic nephropathy and } \\
\text { cardiopathy. }\end{array}$ \\
\hline 19 & $\begin{array}{l}\text { Ficus hispida }(\text { L.f }) \\
\text { Family: Moraceae } \\
\text { Common Name: } \\
\text { Hairy fig. } \\
\text { Vernacular names: } \\
\text { Assamese: } \\
\text { Jagya dumabru. } \\
\text { Bodo: } \\
\text { adumbra }\end{array}$ & $\begin{array}{l}\text { Ripe fruits are eaten } \\
\text { as remedy for } \\
\text { diabetes. It is used } \\
\text { as a supportive } \\
\text { medicine for the } \\
\text { diabetic treatment. }\end{array}$ & $\begin{array}{l}\text { Deepa et al., (2018) found that Ficus benghalensis, } F \text {. } \\
\text { carica, F. glomerata, F. glumosa, F. racemosa, and F. } \\
\text { religiosa exhibited remarkable antidiabetic properties } \\
\text { with various mechanisms of action. Moreover, Ficus } \\
\text { species are versatile sources of bioactive metabolites } \\
\text { such as flavonoids, phenolic acids, tannins, alkaloids, } \\
\text { glycosides, coumarins, triterpenoids, sterols and } \\
\text { vitamin E. These extracts and isolated compounds } \\
\text { significantly have enhanced insulin secretion and } \\
\text { subsequently reduced blood glucose level. }\end{array}$ \\
\hline 20 & $\begin{array}{l}\text { Leucas aspera } \\
\text { Family: Lamiaceae. } \\
\text { Common Name: } \\
\text { Thunbe./ Gumma } \\
\text { Vernacular names: } \\
\text { Assamese: Durun } \\
\text { saak. Bodo: }\end{array}$ & $\begin{array}{l}\text { The plant is believed } \\
\text { to be a liver } \\
\text { corrective herb. It is } \\
\text { used as a potherb } \\
\text { during diabetic } \\
\text { treatment. }\end{array}$ & $\begin{array}{l}\text { Decoction of whole plant is used to alleviate the } \\
\text { symptoms of psoriasis, Chronic skin eruption, painful } \\
\text { swelling and diabetis in folk medicines (Atchutkumar } \\
\text { et. al, 2013) Annapandian and Sundaram (2017) also } \\
\text { stated that the crude extract of Leucas aspera have } \\
\text { exhibited antidiabetic activity. }\end{array}$ \\
\hline
\end{tabular}




\begin{tabular}{|c|c|c|c|}
\hline & Khangsisa. & & \\
\hline 21 & $\begin{array}{l}\text { Andrographis } \\
\text { peniculata. } \\
\text { (Burm.f) wall } \\
\text { Family: Acanthaceae. } \\
\text { Common Name: } \\
\text { Creat/green Chireta. } \\
\text { Vernacular names: } \\
\text { Assamese: Sirotha } \\
\text { teeta/ Kalmegh. } \\
\text { Bodo: Chirota. }\end{array}$ & $\begin{array}{l}\text { Whole plant extract } \\
\text { is used for diabetic } \\
\text { cure. The crude } \\
\text { extract is taken at a } \\
\text { dose of } 1 \text { tea } \\
\text { spoonful in empty } \\
\text { stomach in the } \\
\text { morning hours } \\
\text { before meal }\end{array}$ & $\begin{array}{l}\text { Andrographis paniculata is highly used potential } \\
\text { medicinal plants and is traditionally used for the } \\
\text { treatment of common cold, diarrhoea, fever due to } \\
\text { several infective cause, jaundice, as a health tonic for } \\
\text { the liver and cardiovascular health, and as an } \\
\text { antioxidant. Nugroho et al., (2012) found that purified } \\
\text { extract and andrographolide significantly ( } P<0.05) \\
\text { decreased the levels of blood glucose, triglyceride, and } \\
\text { LDL without effecting serum cholesterol and body } \\
\text { weight. In addition, Andrographis paniculata (Burm. } \\
\text { f.) Nees has shown an antidiabetic effect in type } 1 \\
\text { Diabetes Mellitus and the purified extract of the plant } \\
\text { and its active compound andrographolide for } \\
\text { antidiabetic and antihyperlipidemic effects in Type } 2 \\
\text { Diabetes Mellitus (high-fructose-fat). }\end{array}$ \\
\hline 22 & $\begin{array}{l}\text { Syzygium cumini (L.) } \\
\text { Skeels } \\
\text { Family: Myrtaceae. } \\
\text { Common Name: } \\
\text { Malabar Plum/ Black } \\
\text { plum. } \\
\text { Vernacular names: } \\
\text { Assamese: Kola jamu } \\
\text { Bodo: Gwswm jamu. }\end{array}$ & $\begin{array}{l}\text { Syzygium cumini } \\
\text { (L.) Skeels is one of } \\
\text { the widely used } \\
\text { medicinal plants in } \\
\text { the treatment of } \\
\text { various diseases in } \\
\text { particular } \\
\text { diabetes. Seed } \\
\text { powder about } 1 \\
\text { teaspoonful is taken } \\
\text { with water in the } \\
\text { morning in empty } \\
\text { stomach and also in } \\
\text { the evening before } \\
\text { meals. }\end{array}$ & $\begin{array}{l}\text { The plant is rich in compounds containing } \\
\text { anthocyanins, glucoside, ellagic acid, isoquercetin, } \\
\text { kaemferol and myrecetin. The seeds are claimed to } \\
\text { contain alkaloid, jambosine, and glycoside jambolin or } \\
\text { antimellin, which halts the diastatic conversion of } \\
\text { starch into sugar. (Ayyanar and Subashbabu, 2012). } \\
\text { Antidiabetic effect of Jamun has been indicated in } \\
\text { Ayurvedic pharmacopeia, which states that the seed } \\
\text { powder of Jamun is effective in controlling high blood } \\
\text { sugar levels (Jagetia and Magri (2018). }\end{array}$ \\
\hline 23 & $\begin{array}{l}\text { Scoparia dulcis L.. } \\
\text { Family: } \\
\text { Plantaginaceae. } \\
\text { Common Name: } \\
\text { Licorice weed/ sweet } \\
\text { broom. } \\
\text { Vernacular names: } \\
\text { Assamese: Bon } \\
\text { Bon-dhonia/ Bont } \\
\text { chini/ Modhumehari. } \\
\text { Bodo: } \\
\text { Bonsini. }\end{array}$ & $\begin{array}{l}\text { Scoparia dulcis is } \\
\text { known as sweet } \\
\text { broom weed and is a } \\
\text { perennial herb. } \\
\text { Fresh leaves 5-6 in } \\
\text { number are eaten or } \\
\text { chewed for three } \\
\text { times a day before } \\
\text { meals }\end{array}$ & $\begin{array}{l}\text { Scoparia dulcis has been used in many traditional } \\
\text { medicinal systems as an antidiabetic herb and for a } \\
\text { variety of ailments. This herb can be used as an } \\
\text { antioxidant and also having antidiabetic activity. } \\
\text { (Mishra, 2013). }\end{array}$ \\
\hline
\end{tabular}

Fig.1 Medicinal Plants used for Treating Diabetes in Kokrajhar District of Assam 

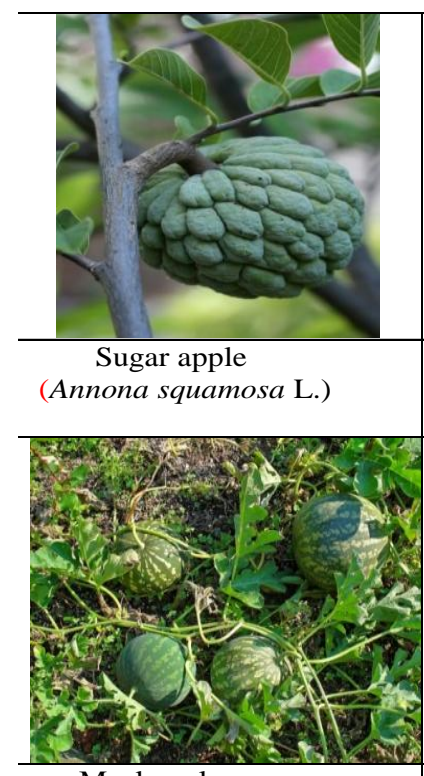

Musk melon

(Citrullus colocynthis(L.)

Schrad)

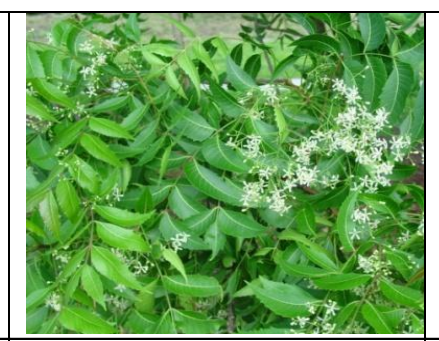

Neem

(Azadirachta indica A.Juss)

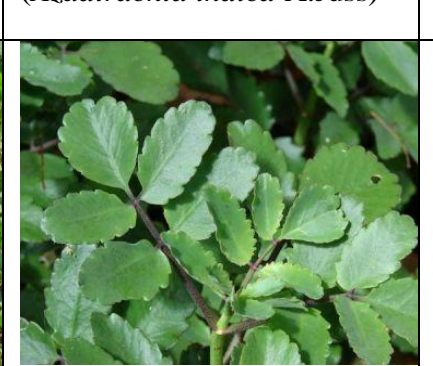

Air plant

(Kalanchoe pinnata Lam. Pers)

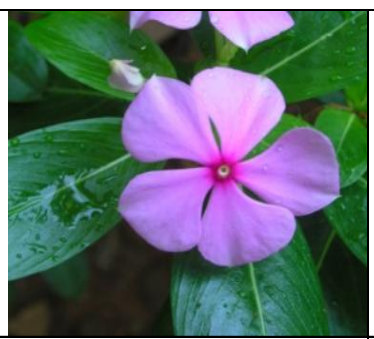

Bright eyes

(Cateranthus roseus (L.) G.Don

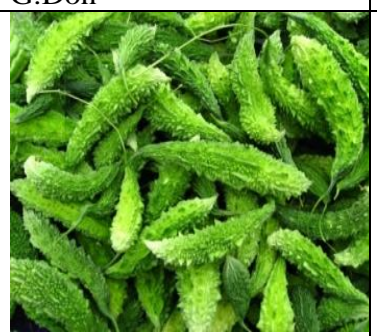

Bitter gourd

(Momordica charantia L.)

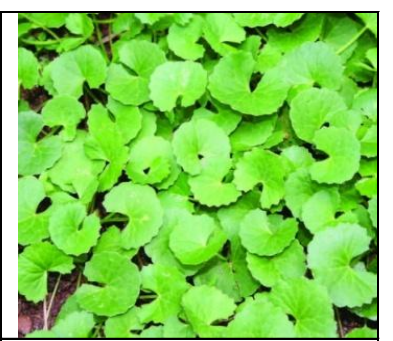

Indian pennywort (Centella asiatica $(\mathrm{L}$. Urban)

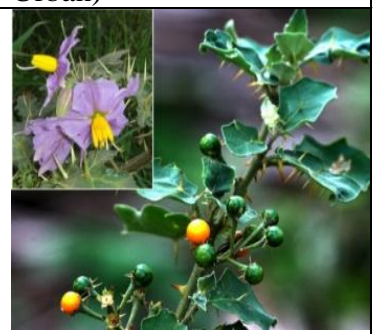

Yellow fruit night shade (Solanum xanthocarpum Schrad \&H.Wendle )

Chinese lard plant (Hodgsonia heteroclite Roxb.)

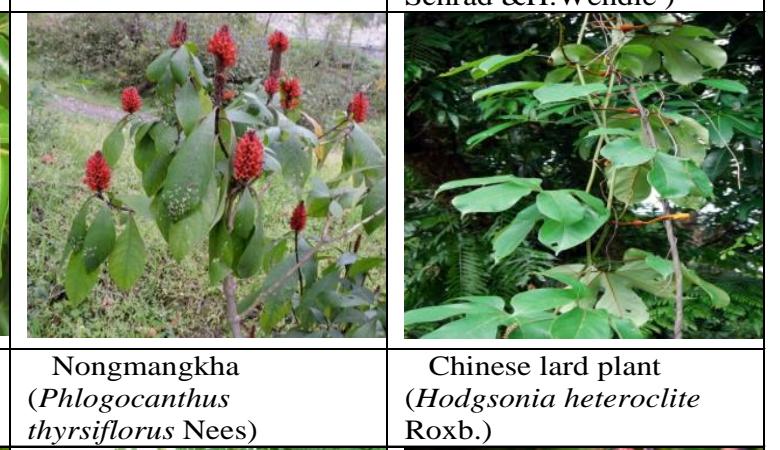
spreng )

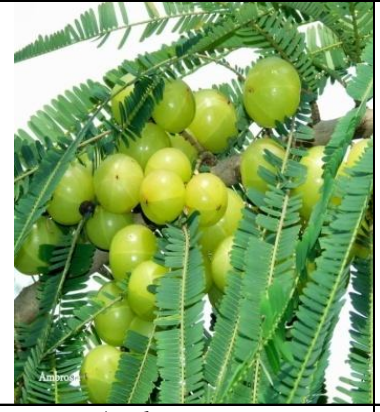

Amla

(Phyllanthus emblica L)

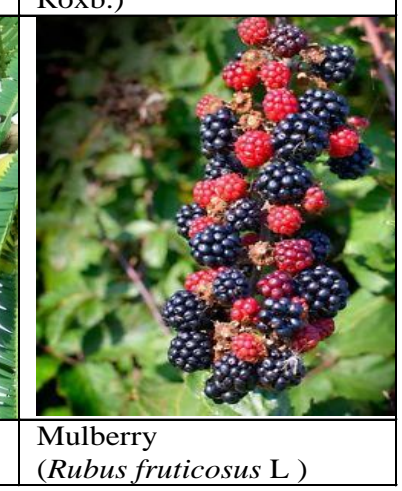

In conclusion the healthcare system of rural India mostly depends on the knowledge of local medicines, mainly derived from plant. Exploring this knowledge will always be beneficial to human kind as this knowledge may lead to effective drug discovery and will act as a first aid to many diseases. Plants are natural antioxidants and effective herbal medicines, in part due to their anti-diabetic compounds, such as flavonoids, tannins, phenolic, and alkaloids that improve the performance of pancreatic tissues by increasing the insulin secretion or decreasing the intestinal absorption of glucose. In the same context, more researches are needed in order to separate the active components of plants and molecular interactions of their compounds for analysis of their curative 
properties not only for diabetes but for other ailment also. Traditional knowledge on medicinal plants is under the threat of extinction with current rate of modernization. Hence, it needs a comprehensive study for documentation of the medicinal plants and their conservation.

\section{Acknowledgement}

We would like to record our appreciation to all those who are involved in identifying and sharing their old aged knowledge on traditional formulation of different enthnomedicinal plant to treat diabetes mellitus for proper documentation of this research paper. We would also like to acknowledge the people of Kokrajhar who are still continuing with their traditional practices to some extent to treat various alignments through herbs. Lastly, we would like to acknowledge all who are directly or indirectly involved by giving patient advice, guidance and unwavering support.

\section{References}

Annapandian VM, Sundaram S, In vitro Antidiabetic Activity of Polar and Nonpolar Solvent Extracts from Leucas aspera (Willd.) Link Leaves, Pharmacognosy Research, 9(3) (2017) 261-261

Asadollahi K, Sayehmiri K, Peygambari R, Abangah R,Therapeutic effects of Citrullus colocynthis fruit in patients with type II diabetes: A clinical trial study, Journal Pharmacy Bioallied Sciences, 8(2) (2015) 130-131

Atchutkumar K, Satyanarayana T, Kiran KR, Rajesh K,. Antihyperglycemic activity of Methanolic extract of Leucus Aspera whole wild plant on blood glucose level of Streotozotocin induced diabetic rat, International Journal of pharmacy and pharmaceutical science, 5(2) (2013) 7678.
Ayenewu KD, Antidiabetic activity of aqueous extract of Vigna radiate in streptozotocin induced diabetic rat, Indo American Journal of pharmaceutical research, 7(2) (2017) 7718-7721.

Ayyanar M and Subashbabu P, Syzygium cumini (L.) Skeels: A review of its phytochemical constituents and traditional uses, Asian Pacific Journal of Tropical Biomedicine, 2(3) (2012) 240246.

Azad AK and Islam O, Phytochemical profiling and evaluation of antioxidant and antidiabetic activity of methanol extract of spinach (Spinacia oleracea l.) Leaves, International Journal of Pharma Sciences and Scientific Research,.4 (1) (2018) 2427.

Basumatary S, Das AK, Raman N, Sarmah GD, Baalan L and Bora R, Phytochemical Screening and Anti Microbial activity of leaf and fruit extract of Hodgsonia heteroclite, Journal of Indian Economic Research for Multidisciplinary 3(2) (2015) 358-366.

Bhatt KC, Semwal DP, Bhandari DC, Panwar NS, A note on distribution, ethnobotany and economic potential of Hodgsonia heteroclita (Roxb.) Hook. F \& Thoms. In North-eastern India, Indian Journal of Natural Products and Resources 5(1)(2014) 88-91.

Bhuyan SI, Medicinal plant used for diabetes treatment by different tribes of Bongaigoan district, North east India, International Journal of advance research in science, engineering and technology, 2(1) (2015) 376-379.

Deepa P, Sowndhararajan K, Kim S, Park S J, A role of Ficus species in the management of diabetes mellitus: A review, Journal of Ethnopharmacology.215 (2018) 210-232.

Desai S, Tatke P,Charantin an important lead compound from Momordica charantia for the treatment of diabetes, Journal of Pharmacognosy and Phytochemistry, 3(6) (2015)163-166.

Devaki K, Suriyamoorthy P, Subrhamanian H, 
Antidiabetic activity of aqueous extract of Erythrina variegata L. Bark in streptozotocin induced diabetic rats, Journal of Chemical and Pharmaceutical Research, 8(4) (2016) 306-312.

Dhakad PK, Sarmah PK, Kumar S, A review on phytochemical studies and biological potential of Citrullus colocynthis(L.) Schrad, Cucurbitaceae, Bioengineering and Bioscience, 5(4) (2017) 55-64

Firdous $\mathrm{H}$ and Marwah S, Benefits Of Black Gram (Urad Dal) And Its Side Effects. (2020)

https://www.lybrate.com/topic/blackgram-urad-dal-benefits-and-side-effects

Gahlawat DK, Jakhar S and Dahiya P,Murraya koenigii (L.) Spreng: An ethnobotanical, phytochemical and pharmacological review, Journal of Pharmacognosy and Phytochemistry; 3 (3) (2014) 109-119.

Gaire BP and Subedi L, Phytochemistry, pharmacology and medicinal properties of Phyllanthus emblica Linn. Chinese Journal of Integrative Medicine. (2015) 1-8.

Giri RP, Gangawane, Ajit K,Giri, Sucheta G,Neem the Wonder Herb: A Short Review, International Journal of Trend in Scientific Research and Development (IJTSRD) 3(3) (2019)

Girish TK, pratapevm and Rao UP, Nutrient distribution, phenolic acid composition, antioxidant and alpha-glucosidase inhibitory potentials of black gram (Vigna mungo L.) And its milled byproducts,Food Research International. 46(1) (2019) 370-7.

Gogoi B, Kakoti B, Bora NS and Goswami AK, Phytochemistry and pharmacology of Phlogacanthus thyrsiflorus nees: A review, International Journal of Pharmaceutical Sciences Review and Research 23(2) (2013) 175-179.

Gomaa E,Yahayu M, Nurjayadi M, Dailin D J and Enshasy $\mathrm{H}$ E, Antimicrobial Compounds from Catharanthus roseus-A review, International journal of scientific \& technology research, 8 (10) (2019) 113-121
Gupta BM, Dhawan SM and Gupta R,. Phyllanthus emblica (Medicinal Plant) Research: A Scientometric Assessment of Global Publications Output during 200817, EC pharmacology and Toxicology.7(1) (2018) 18-28.

Hamilton AC, Medicinal plants, conservation and livelihoods,Biodiversity and Conservation, 13 (8) (2004) 1477-1517.

Haq ZU, Riaz M, feovd, Zafar HZ, Rubus Fruticosus L.: Constituents, Biological Activities and Health Related Uses, Molecules 19(8) (2014) 10998-1029.

Hemalakhmi S and Devaki K, Antidiabetic activity of ethanolic extract of erythrina variegata $l$ flowers on treptozotocin induced diabetic rats thesis. Department of Biochemistry, Partial fulfillment of Phd Degree, Karpagam academy of higher education. Coimbatore, (2017) 1-21

Hodaei H, Adibian M, Nikpayam O, Hedayati M, Sohrab, The effect of curcumin supplementation on anthropometric indices, insulin resistance and oxidative stress in patients with type 2 diabetes: a randomized, double-blind clinical trial. Diabetology \& Metabolic Syndrome, 11 (41) (2019)

Hossain S, Urbi Z, Sule A and Tahman $\mathrm{KMH}$, .Andrographis paniculata (Burm. F.) Wall. Ex Nees: A Review of Ethnobotany, Phytochemistry, and Pharmacology. The scientific world Journal, (2014)

Jagetia GC and Magri H, A review on the role of jamun, syzygium cumini skeels in the treatment of diabetes, International Journal of Complementary and Alternate medicine,. 11 (2) (2018) 91-95

Kaur G, Somaiya R and Patel S, Preventive and Curative Potential of Vigna mungo against Metabolic Syndrome in Acute and Chronic Rat Models, Journal of Biological Sciences, 15 (2015) 85-91.

Kooti W, Farokhipour M, Asadzadeh LDA and Samani MA, The role of medicinal plants in the treatment of diabetes: a systematic review, Electron Physician, 8(1) (2016) 1832-1842. 
Khan MA, Ahmad M, Zafar M and Rehman F, Ethnomedicines for treatment of various diseases in D.I. Khan District, Sarhad Journal of Agriculture, 24 (2) (2008

Meena MK, Meena RC and Patni V, Ethobotanically study of Citrullus colocynthis(L.) Schrad - an important threaten medicinal herbs. Journal of Medicinal Plant Studies. 2(2) (2014) 1522

Mehta D and Balemkar S, Pharmacological activity of spinacia oleracea linn, Asian Journal of Pharmaceutical Research and Development. 2 (1) (2014) 32-42.

Mishra MR, Mishra A, Pradhan DK, Panda AK, Behera RK and Jha S, Antidiabetic and Antioxidant Activity of Scoparia dulcis Linn..Indian Journal of Pharmaceutical Science; 75(5) (2013) 610-614.

Motevalian, M. And Javadpour, S.M. (2017).Anti diabetic effect of black berry extract on normal and STZ induced diabetic rat. Iranian Journal of Pharmacology and Therapeutics. 15:1-10.

Nagar JC and Chauhan LS, Hypoglycemic and hypolipidemic activity of root extract of erythrina variegata in alloxan induced diabetic rat. Asian Journal of biomedical and pharmaceutical Science, 5(46) (2015) 25-30

Narzary H, Brahma S and Basumatary S,Wild edible vegetables consumed by Bodo tribes of Kokrajhar district of Assam, North east India. Archeived of Applied Science Research, 5(5) (2013) 182-190.

Niamnuy C, Charoenchaitrakool M, Mayachiew $\mathrm{P}$ and Devahastin S, Bioactive Compounds and Bioactivities of Centella asiatica (L.) Urban Prepared by Different Drying Methods and Conditions, Drying Technology: an International Journal, 31 (16) (2015) 2007-2015.

Nitin M, Ifthekar SQ and Mumtaz M, Evaluation of hepatoprotective and nephroprotective activity of aqueous extract of Vigna mungo (Linn.) Hepper on rifampicin-induced toxicity in albino rats. International Journal of Health \& Allied
Sciences, 1(2) (2012) 85.

Nugroho AE, Andrie M, Warditani NK, Siswanto E, Pramano S and Lukitaningsih E, Antidiabetic and antihiperlipidemic effect of Andrographis paniculata (Burm. F.) Nees and andrographolide in highfructose-fat-fed rats, Indian Journal of Pharmacology. 44(3) (2012) 377-381.

Oladeji O, Oyebamiji AK, Stellaria Media (L) Vill.- A plant with immense therapeutic Potential: Phytochemistry and pharmacology. Science Direct- Heliyon 6(6) (2020)

Pamunuwa G, Karunaratne, waisundhara VY, Antidiabetic Properties, Bioactive Constituents, and Other Therapeutic Effects of Scoparia dulcis. Evidence based complementary and alternative medicine. Volume 2016.|Article ID 8243215.

(2016)https://doi.org/10.1155/2016/82432 15.

Parmar S, Garwal A, Navin S, Solanum xanthocarpum (Yellow Berried Night Shade): A review, Scholars Research Library, 2(4) (2010) 373-383

Pham MH, Ngo DH, Ngo DN and Vo TS. Investigation of biological activity of wild better melon, Biomolecules.9 (211) (2019) 1-10

Priya FF and Islam MF. Phyllanthus emblica Linn.- a natural gift to human- an overview. Journal of disease and medicinal plant.5 (1) (2019) 1-9.

Rahmani, Arshad Husain, Ahmad Almatroudi, Faris Alrumaihi, Khan and Amjad Ali, Pharmacological and Therapeutic Potential of Neem (Azadirachta indica) Pharmacognosy Reviews | Published by Wolters Kluwer - Medknow 12 (24) (2018) 250-255.

Rivera S, Trujillo MJ and Chaveri JP, Utility of curcumin for the treatment of diabetes mellitus: Evidence from preclinical and clinical studies. Journal of Nutrition and Intermediary Metabolism. 14 (2019) 2941.

Sarmah $M$ and Das B, Medicinal plants of North-east region of India: a small 
review, International Journal of Current Pharmaceutical Research,10 (4) (2018) 11-12.

Shirwaikar A, Rajendran K, Kumar DC and Bodla R. Antidiabetic activity of aqueous leaf extract of Annona squamosa in streptozotocin-nicotinamide type 2 diabetic rats J Ethnopharmacol, 91(2004) 171-5

Shrestha PM and Dhillion SS, Medicinal plant diversity and use in the highlands of Dolakha district, Nepal. J Ethnopharmacol, 86 (2003) 81-96

Sunayana N, Raghavendra VB, Uzma M and Girish ST, Anti-diabetic properties of Kalanchoe pinnata (lam.) Pers. In alloxan induced diabetic mice. Asian Journal of Research in Biological and Pharmaceutical Sciences. 49ik(4) (2016) 143-151

Swargiary A and Brahma D, Phytochemical analysis and antioxidant activity of Hodgsonia heteroclita (Roxb), Indian Journal of Pharmaceutical Science, 79(2) (2017) 212-219

Tekuri SK, Pasupuleti SK., Konidala KK,
Amuru SR, Bassaiahgari P, Pabbaraju N, Phytochemical and pharmacological activity of Solanum SB - a Review. Journal of applied pharmaceutical science, 9(3) (2019) 126-136.

Tomar RS and Sisodia SS, Antidiabetic activity of Annona squamosa Linn. In alloxan induced diabetic rats, International Journal of Green Pharmacy, 4 (2014) 237-241.

Uddin S, Nuri ZN, Alam, Khorshed and Hoq Obydul, Neem (Azadirachta indica) in health care: A review, International Journal of Urrani and Integrative Medicine, 2(2) (2018) 81-87

Zahara K, Bibi Y and Shaista, Tabassum S. Clinical and therapeutic benefits of Centella asiatica- a review, Pure and Applied Biology, 3(4) (2014) 152-159

Zhang DW, Fu M, Gao SH and Liu JL, Curcumin and Diabetes: A Systematic Review. Evidence based complementary and alternative medicine. (2013) https://www.ncbi.nlm.nih.gov/pmc/article s/PMC3857752/

\section{How to cite this article:}

Sarmah, P., M. Neog, M. K. Bhuyan and Basumatary, P. 2021. Ethnomedicinal Plants and their Traditional Use for Treatment of Diabetes in Kokrajhar District of Assam, India. Int.J.Curr.Microbiol.App.Sci. 10(01): 464-477. doi: https://doi.org/10.20546/ijcmas.2021.1001.057 